\title{
Analysis Risk Factors of Stunting Incidence on Toddlers in the Working Area of Porto Haria Public Health Center
}

\author{
Zacarias Latupeirissa ${ }^{1}$, Indar ${ }^{2}$, Amran Razak ${ }^{2}$, Muhammad Alwy Arifin², \\ Andi Zulkifli ${ }^{3}$, Muh. Yusri Abadi ${ }^{2}$, Anwar Mallongi ${ }^{4}$ \\ ${ }^{1}$ Magister Program Departement of Health Administration and Policy, Public Health Hasanuddin University, \\ ${ }^{2}$ Professor and Lecturer of Departement of Health Administration and Policy, Public Health Hasanuddin \\ University, ${ }^{3}$ Professor of Departement of Epidemiology, Public Health Hasanuddin University, ${ }^{4}$ Professor of \\ Departement of Environmental Health, Public Health Hasanuddin University
}

\begin{abstract}
The prevalence of stunting events in Central Maluku Regency is still high, with 26 toddlers experiencing stunting in 2018 and 27 in 2019 at Porto Haria Public Health Center. This study aims to analyze the risk factors of stunting events in toddlers in the working area of Porto Haria Public Health Center. This research is a type of analytical observational research with the design of case control study. The case population in this study was a toddler who was diagnosed stunting in the working area of Porto Haria Public Health Center as many as 37 toddlers and the control population in this study was an not diagnosed toddler stunting in the working area of Porto Hariapublic Health Center as many as 814 toddlers. The sampling used purposive sampling and found 72 toddlers were divided into 36 cases and 36 controls. Data analysis using univariate and bivariate statistical analysis using Odds Ratio. The results showed that the immunization of toddlers scored $\mathrm{OR}=0.680$, health care rating $\mathrm{OR}=0.727$, parental education (family head, $\mathrm{OR}=1,400$, Mother's value $\mathrm{OR}=0.769$ ). Parental education is a risk factor, while toddler immunization and utilization of health services are protective factors. Parents (Mothers) are advised to pay attention to nutritional intake both during pregnancy and afterwards, in order to monitor the growth and development of children in terms of food and drink. For health care institutions, especially in nutrition health workers are expected to provide more intensive information and education about the dangers and causes of stunting.
\end{abstract}

Keywords: Stunting, breast milk history, immunization of toddlers, birth weight, Public health center.

\section{Introduction}

Stunting is defined as a height index by age less than minus two standard deviations (-2 SD) or below the existing standard average. Stunting in children is a long-term result of chronic consumption of low-quality diets combined with morbidity, infectious diseases, and environmental problems ${ }^{1-2}$. The high prevalence of

\footnotetext{
Corresponding Author: Zacarias Latupeirissa

Magister Program Departement of Health

Administration and Policy, Public Health Hasanuddin University

e-mail: caka.latupeirissa@gmail.com
}

stunting in children aged 24-59 months indicates that stunting is unlikely to be reversible ${ }^{3,4}$ so it is necessary to commit from state and local leaders to pay attention to stunting handling in order to lower the prevalence of stunting ${ }^{5}$.Health and stunting are related to politics and culture ${ }^{4-9}$. Health care and stunting actually refer to a setting or regional approach to cover various health problems ${ }^{10-13}$

In Maluku Province, the prevalence of stunting is still volatile from 2016-2018. There was an increase in the prevalence of stunting in 2016 by $29.0 \%$ to $30.0 \%$ in 2017 , however, there was a decrease in the prevalence of stunting toddlers from $30.0 \%$ (2017) to $22.9 \%$ (2018), although there was still a decrease but there were still 7 districts/cities that experienced an increase in the prevalence of toddler stunting from 2016 to 2017 namely 
West Southeast Maluku regency 25 1\% (2016) increased by 31.7 (2017), Southeast Maluku regency $27.8 \%$ (2016) increased by $30.0 \%$ (2017), Central Maluku Regency 23.2\% (2016) 31.4\% (2017), Seram West district 23.6\% (2016) increased 28.9\% (2017), East Seram district 27.4\% (2016) mangalami increase 40.6\% \% (2017), Buru South regency $23.7 \%$ (2016) increased by $31.0 \%$ (2017), and Tual City 27.5\% (2016) increased to $30.1 \%$ (2017). There was an increase in the prevalence of toddler stunting in 2 districts/cities from 2017 to 2018, namely Southeast Maluku regency $30.0 \%$ increased to $31.4 \%$ (2018), and Ambon City 21.9\% (2017) increased to $22.0 \%$ (2018)14. ${ }^{14}$.

The Government of Indonesia is committed to reducing the number of stunting by up to $5 \%$ in 2015. Internationally, Indonesia joined the Nutrition Improvement Movement, a global movement with the aim of giving everyone the right to healthy and nutritious food. In September 2012, Indonesia launched a program called "The First 1000 Days of Life Movement" or the First 1000 Days of Life. This movement aims to encourage improved nutrition for a better future for Indonesian children ${ }^{15,16}$. Public knowledge of the golden age of life or the First 1000 Days of Life needs to be established early, especially for early childhood to improve their understanding in order to become a more qualified generation ${ }^{15}$.

In order to realize the optimal level of health for everyone, there must be constant attention to the implementation of health-minded national development, the guarantee of health care, improved professionalism and decentralization of the field of health ${ }^{5,17}$. The main targets of public health services are the community and certain groups. Meanwhile, for public health services, the workers who serve are public health experts. Thefocus is to prevent disease and the main goal is certainly society as a whole ${ }^{18}$.

But what happens in the field is still high number of stunting incidents, especially in Central Maluku Regency, Maluku Province.Central Maluku Regency is one of the districts of 3 districts designated by the Ministry of Health as locus stunting. Saparua sub-district is one of 17 sub-districts in Central Maluku district with the number of public health centers as many as 3 public health centers namely Porto Haria public health center, Saparua public health center and BooiPaperu public health center. Porto Haria public health center has 2 working areas namely Porto State and HariaState.
Based on the report of stunting coverage according to the Central Maluku District Health Office in 2018 shows that as many as 26 toddlers experienced stunting in Porto Haria public health center. While the number of stunting incidents in Haria State in 2018 was 23 people out of a total of 157 toddlers, and in 2019 a total of 27 people out of a total of 685 toddlers with details namely babies 0-11 months with a male gender of 58 men and women as many as 47 people, while 1-5 years with male sex as many as 295 men and women as many as 285 people $^{14}$.

The problem of nutritional status in toddlers in Indonesia has a disparity between regions/provinces. Based on the size of the stunting problem, a region is considered to have mild stunting problems when the prevalence of stunting is between $20-29 \%$, moderate when $30-39 \%$ and weight when $\geq 40 \%{ }^{19,20}$. The problem of stunting is one of the problems faced by the world, especially in poor and developing countries. Stunting becomes a health problem because it is related to the risk of pain and death, suboptimal brain development, so that motor development becomes late and inhibits mental growth. This poses a serious threat to the existence of children as the next generation of a nation. Stunting is a poor predictor of the widely accepted quality of human resources, which then degrades a nation's productive capabilities in the future ${ }^{21}$.

There are various factors that are the cause of stunting in toddlers. According to Rachmi et al research (2016), some of the risk factors for stunting events stem from child factors such as gender, anthropometry at birth, lactation history and age of complementary food recognition, from parental factors such as parental age, marital status, parental anthropometry such as weight and height, antenatal care history, parental education, and family wealth, as well as from soy factors such as residence, type of residence, caste class, ecological environment, and geographical location ${ }^{22}$.

The utilization of health services has an influence on stunting events due to the incidence of disease infection (morbidity) closely related to access and utilization of health services. In addition, the health and sanitation services of the environment are also closely related to morbidity and ultimately affect nutritional status ${ }^{23}$.

Based on the data of toddlers in the working area of Haria public health center there are 62 toddlers from 2 countries in the working area of Porto Haria public health center is a stunting person. This kind of 
thing the community needs to get mentoring because the community has not been able to be empowered independently. Problems like this need special treatment and prevention should be carried out early on. Because stunting cannot be cured directly. However, early prevention can lower the risk of stunting in future generations.

Basically there are already programs held by the Public Health Center such as the administration of blood-added tablets in the working area of portoharia public health center. The administration of blood-added tablets is carried out every week precisely on fridays. However, these programs have not had a significant effect in solving stunting problems in the working area of portoharia public health center. This is because the programs are caricature and temporary. The purpose in this study was to analyze the risk factors of stunting events in toddlers in the working area of portoharia public health center

\section{Materials and Method}

The type of research used in this study is analytical observational research with the design of the Case Control Study. The case population in the study was a toddler diagnosed stunting in the working area of portoharia public health center as many as 37 toddlers and the control population in this study was an undiagnosed toddler stunting in the working area of Porto Haria public health center as many as 814 toddlers. The sampling used purposive sampling and found 72 toddlers were divided into 36 cases and 36 controls. Data analysis using univariate and bivariate statistical analysis using Odds Ratio.

\section{Results}

Table 1. Distribution of the Characteristics of Research Variables and Stunting Management in the Case and Control Group in the Work Area of the Porto Hariapublic Health Center in 2020

\begin{tabular}{|c|c|c|c|c|c|c|}
\hline \multirow{3}{*}{ Variable Characteristics } & \multicolumn{4}{|c|}{ Group } & \multirow{2}{*}{\multicolumn{2}{|c|}{ Total }} \\
\hline & \multicolumn{2}{|c|}{ Case } & \multicolumn{2}{|c|}{ Control } & & \\
\hline & $\mathbf{n}$ & $\%$ & $\mathbf{n}$ & $\%$ & $\mathbf{n}$ & $\%$ \\
\hline \multicolumn{7}{|l|}{ A. Toddler Immunization } \\
\hline High risk & 10 & 27.8 & 13 & 36.1 & 23 & 32.0 \\
\hline Low Risk & 26 & 72.2 & 23 & 63.9 & 49 & 68.0 \\
\hline Total & 36 & 100.0 & 36 & 100.0 & 72 & 100.0 \\
\hline \multicolumn{7}{|c|}{ B. Utilization of Health Services } \\
\hline High risk & 3 & 8.3 & 4 & 11.1 & 7 & 9.8 \\
\hline Low Risk & 33 & 91.7 & 32 & 88.9 & 65 & 90.2 \\
\hline Total & 36 & 100.0 & 36 & 100.0 & 72 & 100.0 \\
\hline \multicolumn{7}{|l|}{ C. Parents Education } \\
\hline \multicolumn{7}{|c|}{ 1. Family Head Parents Education } \\
\hline High risk & 21 & 58.3 & 18 & 50.0 & 39 & 54.1 \\
\hline Low Risk & 15 & 41.7 & 18 & 50.0 & 33 & 45.9 \\
\hline Total & 36 & 100.0 & 36 & 100.0 & 72 & 100.0 \\
\hline \multicolumn{7}{|c|}{ 2. Parenting Education of the child's mother } \\
\hline High risk & 24 & 66.7 & 26 & 72.2 & 50 & 69.4 \\
\hline Low Risk & 12 & 33.3 & 10 & 27.8 & 22 & 30.6 \\
\hline Total & 36 & 100.0 & 36 & 100.0 & 79 & 100.0 \\
\hline
\end{tabular}

Source: Primary Data 2020 
Table 1 shows the distribution of respondents based on research variables. Based on the variable immunizations of toddlers in the case and control groups each showed a lower risk of 26 people (72.2\%) and 23 (63.9\%). Based on the variable utilization of posyandu in the case and control groups each showed more low risk of 33 people (91.7\%) and $32(88.9 \%)$. Based on the educational variables parents show for the education of the head of the family in the case group more high risk as much as 21 people (58.3\%) and the control group at both low and high risk showed as many as 18 people (50.0\%). While the education of parents (Mothers) in the case group and control group each showed a high risk of 24 people $(66.7 \%)$ and $26(72.2 \%)$.

Table 2. Analysis of Research Variables in the Work Area of the Porto HariaPublic health center in 2020

\begin{tabular}{|c|c|c|c|c|c|c|}
\hline \multirow{2}{*}{ Variables } & \multicolumn{2}{|c|}{ Case } & \multicolumn{2}{|c|}{ Control } & \multirow{2}{*}{$\begin{array}{c}\text { OR } \\
(95 \% \text { CI, LL-UL) }\end{array}$} & \multirow{2}{*}{$\begin{array}{c}\mathbf{P} \\
\text { Value }\end{array}$} \\
\hline & n (36) & $\%$ & n (36) & $\%$ & & \\
\hline \multicolumn{7}{|c|}{ Toddler Immunization } \\
\hline High risk & 10 & 72.2 & 13 & 63.9 & 0.680 & 0.449 \\
\hline Low Risk & 26 & 27.8 & 23 & 36.1 & $(0.251-1,845)$ & \\
\hline \multicolumn{7}{|c|}{ Utilization of Health Services } \\
\hline High risk & 3 & 91.7 & 4 & 88.9 & 0.727 & 0.692 \\
\hline Low Risk & 33 & 8.3 & 32 & 11.1 & $(0.151-3.510)$ & \\
\hline \multicolumn{7}{|c|}{ Parents Education } \\
\hline \multicolumn{7}{|c|}{ Family Head Parents Education } \\
\hline High risk & 21 & 41.7 & 18 & 50.0 & 1,400 & 0.478 \\
\hline Low Risk & 15 & 58.3 & 18 & 50.0 & $(0.552-3,550)$ & \\
\hline \multicolumn{7}{|c|}{ Parenting Education of the child's mother } \\
\hline High risk & 24 & 33.3 & 26 & 27.8 & 0.769 & 0.609 \\
\hline Low Risk & 12 & 66.7 & 10 & 72.2 & $(0.281-2.104)$ & \\
\hline
\end{tabular}

Source: Primary Data, 2020

Based on Table 2 of health service utilization variables the results of statistical test analysis show that the value of $\mathrm{OR}=0.727$ (CI 95\%: 0.151-3,510) means that this variable can only act as a protective factor rather than as a risk factor for stunting events. Similarly, the parental education variables of statistical test analysis show that in the education of parents (head of family) the value of $\mathrm{OR}=1,400$ (CI 95\%: 0.552-3550) means that parental education is a risk factor for stunting events. While in parent education (Mother) value $\mathrm{OR}=0.769$ (CI 95\%: 0.281-2.104)which means that this variable is a protective factor against stunting events.

\section{Discussion}

Immunization is the process of inducing artificial immunity both by vaccination (active immunization) and by administering antibodies (passive immunization)
(Peter, 2003) ${ }^{24}$ Immunization in children has an important goal which is to reduce the risk of mordibitas (pain) and mortality (death) of children due to diseases that can be prevented by immunization ${ }^{25}$. The OR scores obtained show that This is in line with research conducted by Swathma, Lestari \& Ardiansyah (2016) showing that most toddlers have obtained complete basic immunizations in both the case group and the control group ${ }^{26}$.

Toddler immunization can play a protective role in stunting. It also means that toddlers with good or complete immunizations can reduce the risk of stunting. The OR scores obtained show that this is in line with research conducted by Swathma et al (2016) showing that most toddlers have received complete basic immunizations in both the case group and the control group ${ }^{16}$. Similarly, research conducted by Azriful et al (2018) shows that 
toddlers who do not get fully immunized are more at risk of stunting because immunization is one way of preventing infectious diseases, especially PD3I given to both infants and adults. However, complete immunization does not guarantee a person not to experience the disease as it can be affected by the benefits and effectiveness of immunizations such as the quality of the given vaccine. Therefore, either a fully immunized or incomplete child has the same opportunity to experience stunting 27

The cause of the onset of nutritional problems is multifactor consisting of direct and indirect factors. Therefore, basic health service efforts are directed towards improving the health and nutritional status of children so as to avoid early death and low physical quality ${ }^{28}$. In the utilization of health services is not separated from the efforts of health officials to encourage the public in order to socialize the activities that exist in the health service both health promotion efforts, disease prevention, treatment and recovery of Health ${ }^{29-32}$.

\section{Conclusion}

The study concluded that the immunization of toddlers is a protective factor against stunting events in the working area of portoharia public health center. Toddlers with the utilization of health services are protective factors of stunting events in the working area of Porto Haria community health center.Variable parental education (parental education-head family is a risk factor, while parent-mother education is a protective factor in the occurrence of stunting events in the working area of Porto HariaPublic health center. Parents (Mothers) are advised to pay attention to nutritional intake both during pregnancy and afterwards, in order to monitor the growth and development of children in terms of food and drink. For health care institutions, especially in nutrition health workers are expected to provide more intensive information and education about the dangers and causes of stunting

Ethical Clearance: Taken from University ethical clearance committee.

\section{Source of Funding: Self}

\section{Conflict of Interest: Nil.}

\section{References}

1. Richard D. Semba SdP, Kai Sun, Mayang Sari, Nasima Akhter, Martin W. Bloem. Effect of parental formal education on risk of child stunting in Indonesia and Bangladesh: a cross-sectional study. The Lancet. 2008;371(9609):7.

2. Gani AA, Widasari L, Otoluwa AS, Hadju V, Palutturi S, Thaha AR. Risk factors for stunting among children in Banggai Regency, Indonesia. Enfermería Clínica. 2020;30:149-152.

3. Anisa P. Faktor-faktor yang berhubungan dengan Kejadian Stunting pada Balita Usia 25-60 bulan di Kelurahan Kalibaru Depok tahun 2012. Universitas Indonesia. 2012.

4. Kamba I, Razak A, Saefuddin S, Palutturi S. Video Effect for the Prevention of Knowledge Increasing Stunting in State High School 1 Children in Topoyo Central Mamuju. Indian Journal of Public Health Research \& Development. 2019;10(10):14221427.

5. Palutturi S, Syam A, Asnawi A. Stunting in a political context: A systematic review. Enfermería Clínica. 2020;30:95-98.

6. Kamba I, Razak A, Saifuddin S, Palutturi S. The Effect of Video on the Change of Attitude Toward Stunting Prevention among Children in State Senior High School 1 Topoyo, Central Mamuju. Indian Journal of Public Health Research \& Development. 2019;10(8):1315-1320.

7. Asrina A, Palutturi S, Tenri A. Dole-Dole Tradition in Health Seeking Behavior of Buton Society, Southeast Sulawesi. Indian Journal of Public Health Research \& Development. 2018;9(7):270-274.

8. Asrina A, Palutturi S, Andayanie E. Culture and health behavior of buton society of Baubau City, Southeast Sulawesi. Indian Journal of Public Health Research \& Development. 2018;9(9):315-318.

9. Syam A, Palutturi S, Djafar N, Astuti N, Thaha AR. Micronutrients and growth of children; a literature review. International Journal of Medical Science and Public Health. 2016;5(10):1981-1987.

10. Palutturi S, Rutherford S, Davey P, Chu C. Comparison Between Healthy Cities and Adipura in Indonesia. Malaysian Journal of Medicine and Health Sciences. 2013;9(1):35-43.

11. Palutturi S, Zulkifli A, Syam A. The Key Challenges and Recommendations for Healthy Cities Implementation of North Kolaka, Indonesia. Indian Journal of Public Health Research \& Development. 2017;8(2):252-257.

12. Palutturi S, Chu C, Moon JY, Nam EW. A comparative study on healthy city capacity 
mapping: Indonesia and Korea. The Social Sciences. 2015;10(6):848-854.

13. Palutturi S, Arifin MA. Re-Standardization Makassar Healthy City based on Local Needs. Indian Journal of Public Health Research \& Development. 2019;10(2).

14. Dinkes Provinsi Maluku. Profil Kesehatan Provinsi Maluku Tahun 2019. Provinsi Maluku: Dinas Kesehatan Provinsi Maluku;2019.

15. Putri OQ, Arimbi DQ, Fauzi HD. Study on Stunting Prevention Program in Indonesia: a Literature Review. Paper presented at: ASEAN/ Asian Academic Society International Conference Proceeding Series2016.

16. Brahima JJ, Noor NN, Jafar N. Immunization and distance relationship status on the birth events 1000 HPK stunting work in bone health district Barebbo. Enfermería Clínica. 2020;30:318-322.

17. Indar. Konsep dan Perspektif Etika dan Hukum Kesehatan. Yogyakarta: Pustaka Pelajar; 2014.

18. Indar. Etikolegal Dalam Pelayanan Kesehatan. Yogyakarta: Pustaka Pelajar; 2017.

19. World. Repositioning Nutrition as Central to Development: A Strategy for Large-Scale Action. 2006.

20. Gani AA, Palutturi S, Otoluwa AS, et al. Nutritional status of children under 5 and environmental situation of the household in Banggai Regency. Enfermería Clínica. 2020;30:153-158.

21. UNICEF. Ringkasan kajian gizi Ibu dan Anak. Jakarta. Diunduh dari https://www. unicef. org/ indonesia/id/A6 B_Ringkasan_Kajian_Gizi. f. 2012.

22. Rachmi CN, Agho KE, Li M, Baur LA. Stunting, underweight and overweight in children aged 2.0-4.9 years in Indonesia: prevalence trends and associated risk factors. PloS one. 2016;11(5):e0154756.

23. Aditianti. Faktor determinan stunting pada anak usia 24-59 di Indonesia. Info Pangan dan Gizi. 2010;19(2):42-43.

24. Permata Y. Kelengkapan Imunisasi Dasar Anak Balita dan Faktor-faktor yang Berhubungan di
Rumah Sakit Mary Cileungsi Hijau Bogor, Maret 2008 (Skripsi). Jakarta: FK UI. Permenkes RI Nomor. 2009;42.

25. Narendra MB, Sularyo TS, Soetjiningsih SS, Ranuh I, Wiradisuria S. Tumbuh kembang anak dan remaja. Jakarta: Sagung Seto. 2002.

26. Dandara Swathma HL, Ririn Teguh Ardiansyah. Analisis Faktor Risiko BBLR, Panjang Badan Bayi Saat Lahir dan Riwayat Imunisasi Dasar Terhadap Kejadian Stunting Pada Balita Usia 12-36 Bulan Di Wilayah Kerja Puskesmas Kandai Kota Kendari Tahun 2016. Jurnal Ilmiah Mahasiswa Kesehatan Masyarakat. 2016;1(3):10.

27. Azriful A, Bujawati E, Habibi H, Aeni S, Yusdarif Y. Determinan Kejadian Stunting Pada Balita Usia 24-59 Bulan di Kelurahan Rangas Kecamatan Banggae Kabupaten Majene. Al-sihah: The Public Health Science Journal. 2018;10(2).

28. Brotojoyo U. Manajemen Pelayanan Kesehatan Sebagai Upaya Peningkatan Ekonomi. 2006.

29. Amriani Madani S, Indar. FAKTOR YANG BERHUBUNGAN PEMBERIAN ASI EKSKLUSIF DIWILAYAH KERJA PUSKESMAS PEKKAE KABUPATEN BARRU. ISSN. 2014;3(6).

30. Mallongi A, et al. Potential ecological risks of mercury contamination along communities area in tonasa cement industry Pangkep, Indonesia. EnfermClin. 2020. https://doi.org/10.1016/j. enfcli.2019.10.054

31. Mallongi A, et al. Health risk analysis of phenol and arsenic exposure among kokoda communities village Sorong, West Papua. Enferm Clin. 2020. https://doi.org/10.1016/j.enfcli.2019.10.055

32. Anwar Mallongi, Stang, Syamsuar, HasnawatiAmqam, AminuddinSyam, SyahrulBasri, Muh. Saleh., Target Cancer Risks Due To The Exposure From Silica Among The Communities Living Surround Cement Tonasa Industry Pangkep, Indonesia. Interciencia Journal. 2019 44(11) 